\title{
Methane excretion in the growing pig
}

\author{
BY KIRSTEN CHRISTENSEN* AND GRETE THORBEK \\ National Institute of Animal Science, Rolighedsvej 25, DK-1958 Frederiksberg C, \\ Denmark
}

(Received 9 September 1986 - Accepted 3 November 1986)

\begin{abstract}
1. Total methane excretion $\left(\mathrm{CH}_{4}\right.$ in breath + flatus) was measured in two experiments with thirty-six castrated male pigs (Danish Landrace) during the growth period from 20 to $120 \mathrm{~kg}$ live weight (LW). In Expt A, twenty-eight pigs were fed on a commercial diet alternately at high (HFL; metabolizable energy (ME) 1234 (sE 41) $\mathrm{kJ} / \mathrm{kg}$ $\mathrm{LW}^{0^{075}}$ ) or low (LFL; ME 784 (SE 31) $\mathrm{kJ} / \mathrm{kg} \mathrm{LW}^{075}$ ) feed levels in different weight classes. In Expt B, eight pigs were constantly fed on a semi-purified diet at HFL without (-oil) or with $90 \mathrm{~g}$ soya-bean oil $/ \mathrm{kg}$ diet (+oil) corresponding to daily intakes of ME of 1339 (SE 11) and 1413 (SE 8) kJ/kg LW LW $^{0.75}$ respectively.

2. $\mathrm{CH}_{4}$ excretion was measured during $24 \mathrm{~h}$ respiration trials in open-air-circulation chambers.

3. About 1 litre $\mathrm{CH}_{4}$ was excreted per day at $20-25 \mathrm{~kg} \mathrm{LW}$ increasing to a maximum of 12 litres at $120 \mathrm{~kg} \mathrm{LW}$, which corresponded to no more than $1.2 \%$ of dietary gross energy.

4. In Expt $\mathrm{A}, \mathrm{CH}_{4}$ excretion increased linearly with $\mathrm{LW}$, while in Expt $\mathrm{B}$ the increase was linear until about $70 \mathrm{~kg} \mathrm{LW}$, when it reached a plateau. On average LFL reduced $\mathrm{CH}_{4}$ excretion by $23 \%$ compared with $\mathrm{HFL}$. When related to dry matter (DM) intake, however, the pigs on $\mathrm{LFL}$ excreted $3 \cdot 1$ litres $\mathrm{CH}_{4} / \mathrm{kg}$ dietary DM and those on HFL 2.5 litres $\mathrm{CH}_{4} / \mathrm{kg}$ dietary DM, the difference being significant $(P<0.05)$. In Expt $\mathrm{B}$ the inclusion of soya-bean oil in the basal diet (+oil) reduced $\mathrm{CH}_{4}$ excretion by $26 \%$ compared with the diet without oil (-oil). The pigs receiving the basal diet excreted $5 \cdot 2$ litres $\mathrm{CH}_{4} / \mathrm{kg} \mathrm{DM}$ and the pigs receiving soya-bean oil $4 \cdot 3$ litres $\mathrm{CH}_{4} / \mathrm{kg} \mathrm{DM}$, the difference being highly significant $(P<0 \cdot 001)$. All differences between Expt $\mathrm{A}$ and $\mathrm{B}$ in $\mathrm{CH}_{4}$ excretion based on DM intake were highly significant $(P<0 \cdot 001)$.

5. The results are discussed in relation to gas production in ruminants, rats and humans. It is suggested that flatus production may not only be reduced by changing the composition of the dietary carbohydrates, but also by inclusion of a polyunsaturated oil in the diet of simple-stomached animals and humans.
\end{abstract}

Fermentation of carbohydrates in the hind-gut results in the formation of gases including hydrogen, carbon dioxide and methane. The main part is excreted in flatus, while a smaller part is absorbed into the bloodstream and excreted in expired air. $\mathrm{CH}_{4}$ production has been studied extensively in ruminants and in vitro, but to a lesser extent in the hind-gut in simple-stomached animals and in man.

In the rumen, $\mathrm{CH}_{4}$ is formed by reduction of $\mathrm{CO}_{2}$ and, to some extent, from formate (Hungate, 1968). $\mathrm{CH}_{4}$ excretion represents a loss of dietary energy as it contains $39 \cdot 55 \mathrm{~kJ} / 1$ (Brouwer, 1965). In growing calves the total loss of $\mathrm{CH}_{4}$ amounts to 50-100 litres daily depending on the size of the animal, feed composition, feed level and digestibility of the feed, and it constitutes a loss of energy corresponding to $4-11 \%$ of dietary gross energy (GE) (Thorbek, 1980).

$\mathrm{CH}_{4}$ production in the hind-gut of growing pigs amounts to only a few litres daily and represents an energy loss of about $0 \cdot 2-1 \cdot 0 \%$ of GE (Verstegen, 1971; Hoffmann et al. 1977; Jentsch \& Hoffmann, 1977; van der Honing et al. 1982). In sows of about $200 \mathrm{~kg}$ live weight (LW) and partly fed on grass, the energy loss increased to a maximum of $3.5 \%$ of GE (Breirem, 1935). Generally the energy loss in $\mathrm{CH}_{4}$ is not taken into consideration when estimating feed values for pigs. In man, flatus production is becoming of interest, both in health and disease, and recently the pig was suggested as an appropriate model for studying fermentation in the human gut (Fleming \& Wasilewski, 1984).

In studies on nitrogen and energy metabolism in growing pigs from 20 to $120 \mathrm{~kg} \mathrm{LW}$

* Present address: Royal Veterinary and Agricultural University, Institute of Animal Physiology, Thorvaldsensvej 40, DK-1871 Frederiksberg C, Denmark. 
(Thorbek et al. 1984; Christensen, 1985), $\mathrm{CH}_{4}$ excretion was measured simultaneously. The results of the measurements carried out in relation to the quality and quantity of feed are presented in the present paper.

\section{MATERIALS AND METHODS}

\section{Animals}

The present investigation included two experiments with castrated male pigs (Danish Landrace) from 20 to $120 \mathrm{~kg} \mathrm{LW}$. In the first experiment (Expt A) twenty-eight pigs were fed on a commercial diet at a level which was alternately high (HFL) or low (LFL) and measured in balance periods in different weight ranges from 20 to $120 \mathrm{~kg} \mathrm{LW}$. In the second experiment (Expt B) eight pigs were fed continuously on a semi-purified diet with (+oil) or without ( - oil) a supply of soya-bean oil and measurements made in consecutive balance periods during the growth period.

The pigs, acquired at a mean age of $65 \mathrm{~d}$ and a mean $\mathrm{LW}$ of $18 \mathrm{~kg}$, were initially adapted and were fed on barley + skim-milk powder and treated with Piperazin (Danmarks Apotekerforenings Kontrollaboratorium) for deworming, before they were allocated to their different diets and feed levels. The measurements in both experiments started with a mean initial LW of $25 \mathrm{~kg}$ and, except for two pigs, all animals were healthy and eating their stipulated rations. One pig in Expt $A$ in the final weight range $(105-115 \mathrm{~kg}$ ) refused feed and the results were omitted. One pig in Expt B died suddenly before period 4. At autopsy it showed pale, soft and exudative muscle.

\section{Diets}

A commercial feed mixture was used in Expt A, having a composition as shown in Table 1. Based on its composition it was calculated to contain $17 \mathrm{~g}$ fat and $48 \mathrm{~g}$ crude fibre $/ \mathrm{kg}$. From the measurements of energy metabolism (Thorbek et al. 1984) the metabolizability (metabolizable energy (ME) : gross energy (GE)) was found to be 0.78 , and the content of $\mathrm{ME}$ in the feed mixture was $12.9 \mathrm{MJ} / \mathrm{kg}$. The pigs were fed alternately at high (HFL) and low (LFL) feed levels. The daily intake of ME was 1234 (SE 41) and 784 (SE 31) kJ/kg $L W^{0 \cdot 75}$ at $\mathrm{HFL}$ and LFL respectively.

In Expt B a semi-purified diet was given (Table 1) which contained $9.5 \mathrm{~g}$ fat and $38 \mathrm{~g}$ crude fibre $/ \mathrm{kg}$. The diet was given without (-oil) or with (+oil) the addition of $90 \mathrm{~g}$ soya-bean oil $/ \mathrm{kg}$. Measurements of energy metabolism (Christensen, 1985) showed that the $\mathrm{ME}$ content was 14.3 and $14.5 \mathrm{MJ} / \mathrm{kg}$ in the (-oil) and (+oil) diets respectively. The daily intake of ME was 1339 (SE 11) and 1413 (SE 8) $\mathrm{kJ} / \mathrm{kg} \mathrm{LW}^{0.75}$ for pigs fed on the (-oil) and ( + oil) diets respectively.

\section{Experimental plan}

In Expt A, twenty-eight pigs were distributed in different LW ranges as shown in Table 2. Each pig was measured individually in their respective LW ranges; half the pigs started on LFL and the other half on HFL in order to obtain approximately the same age and $\mathrm{LW}$ in each range. Eight pigs were measured in the lower as well as in the higher $\mathrm{LW}$ ranges, while eight pigs were measured only in the higher LW ranges. In the intervening periods the pigs were kept in individual pens in the stable and fed on HFL. With one pig omitted from the final LW range a total of 126 measurements of the $\mathrm{CH}_{4}$ excretion were carried out.

In Expt B, in which the pigs were maintained throughout on one of the experimental diets, four pigs were given the basal diet and four pigs the basal diet containing soya-bean oil. Measurements were made every fortnight in eight balance periods during the growth 
Table 1. Composition of experimental diets $(\mathrm{g} / \mathrm{kg}$ diet $)$

\begin{tabular}{lclc}
\hline \multicolumn{1}{c}{ Expt A } & \multicolumn{2}{c}{ Expt B } \\
\hline Ingredients & 770 & Ingredients & \\
$\quad$ Barley & 50 & Maize starch & 292 \\
Oats & 140 & Cassava meal & 185 \\
Soya-bean meal & 20 & Slucose & 65 \\
Meat and bone meal & 20 & Cellulose & 65 \\
Mineral and vitamin mix & & Skim-milk powder & 33 \\
Analysis & 893 & Soya-bean meal & 160 \\
$\quad$ Dry matter & 165 & Casein & 80 \\
Protein & $16 \cdot 48$ & Mineral and vitamin mix & 40 \\
Gross energy $(\mathrm{MJ} / \mathrm{kg})$ & & Analysis & 40 \\
& & Dry matter & 900 \\
& & Protein & 183 \\
& & Gross energy $(\mathrm{MJ} / \mathrm{kg})$ & $15 \cdot 76$ \\
\hline
\end{tabular}

Table 2. Expt A. Distribution of animals in different live weight ranges

\begin{tabular}{|c|c|c|c|c|c|c|}
\hline \multirow{2}{*}{$\begin{array}{l}\text { Animal } \\
\text { no. }\end{array}$} & \multicolumn{6}{|c|}{ Live wt range $(\mathrm{kg})$} \\
\hline & $20-25$ & $25-35$ & $50-60$ & $65-75$ & $90-10$ & $5-120$ \\
\hline 1,4 & $x$ & $x$ & & . & $x$ & $x$ \\
\hline 2,3 & $x$ & $x$ & . & . & . & . \\
\hline 6,7 & $x$ & $x$ & . & . & $x$ & $x$ \\
\hline 5,8 & $x$ & $x$ & . & . & . & . \\
\hline $9,10,11,12$ & $x$ & $x$ & . & . & . & . \\
\hline $17,18,19,20$ & $x$ & $x$ & . & . & . & . \\
\hline $21,22,23,24$ & $x$ & . & $x$ & & . & . \\
\hline $13,14,15,16$ & . & . & $x$ & $x$ & . & . \\
\hline $25,26^{*}, 27,28$ & . & . & . & & $x$ & $x$ \\
\hline Nos. of animals & 20 & 16 & 8 & 4 & 8 & 7 \\
\hline
\end{tabular}

Each animal was measured individually on high (HFL) and low (LFL) feeding levels in their respective live weight ranges.

* No. 26 refused feed in the final weight range and the results were omitted.

period from 25 to $115 \mathrm{~kg} \mathrm{LW}$, giving a total of fifty-nine measurements of the $\mathrm{CH}_{4}$ excretion, as one pig died before period 4.

At each feeding level all measurements were carried out with a $7 \mathrm{~d}$ preliminary period followed by a $7 \mathrm{~d}$ balance period in which a $24 \mathrm{~h}$ respiration experiment was placed in the middle of the balance period. The pigs were kept in individual pens in the stable during the preliminary periods and in individual metabolic crates in the balance periods. The temperature in the stable as in the respiration chambers was kept at $22^{\circ}$ at the beginning of the experiments decreasing to $18^{\circ}$ in the later periods. All pigs were fed twice daily and received water ad lib.

\section{Instrumentation}

The $\mathrm{CH}_{4}$ excretion over $24 \mathrm{~h}$ was measured by means of a respiration unit working according to the open-air-circulation principle (Thorbek, 1969). The unit, consisting of two independently-working respiration chambers, had an accuracy of $1.0-1.5 \%$ and was 
frequently calibrated by means of $\mathrm{CO}_{2}$-test gas. The flow of the air through the respiration chambers was kept between 6000 and 6500 litres/h at normal conditions $\left(760 \mathrm{~mm}, 0^{\circ}\right)$. The volume of the outgoing air was measured continuously from the differential pressure over an orifice in the pipe by means of a Barton cell. The electrical signal from the instrument together with signals from the measurements of vacuum and temperature in the pipe and the barometric pressure were transformed to an analogue computer for calculation of the volume of the air at normal conditions.

The $\mathrm{CH}_{4}$ concentration in the outgoing air was measured partly continuously for registration and partly in representative samples of the air by means of a gas analyser (URAS; Hartmann \& Braun, Frankfurt), based on the absorption spectra of the gases from infrared radiation, working in the range $0-0.2 \% \mathrm{CH}_{4}$. The instrument was frequently calibrated by means of $\mathrm{CH}_{4}$-test gas over the range found during animal studies. With the measurement of the total air flow over $24 \mathrm{~h}$ and the mean concentration of $\mathrm{CH}_{4}$ in the air, the total amount of $\mathrm{CH}_{4}$ excreted in flatus and expired air was calculated. The data obtained were analysed statistically by Student's $t$ test, and ANOVA in accordance with Snedecor (1956).

\section{RESULTS}

The results from the measurements of the $\mathrm{CH}_{4}$ excretion in Expts $\mathrm{A}$ and $\mathrm{B}$ are shown in Tables 3 and 4 respectively. The excretion amounted to a maximum of 14 litres $\mathrm{CH}_{4} / 24 \mathrm{~h}$. The air flow was about 150000 litres $/ 24 \mathrm{~h}$ in order to keep a $\mathrm{CO}_{2}$ concentration below $1 \%$ in the chamber. Thereby the $\mathrm{CH}_{4}$ concentration varied from $0.001 \%$ in the first period increasing to $0.01 \%$ in the later periods. The individual variation in $\mathrm{CH}_{4}$ excretion in the different $\mathrm{LW}$ groups was great with coefficients of variation (CV) from 2 to $70 \%$.

The daily $\mathrm{CH}_{4}$ excretion in Expt $\mathrm{A}$ increased linearly with $\mathrm{LW}$ on both feed levels. The pigs on LFL showed a lower $\mathrm{CH}_{4}$ excretion in all $\mathrm{LW}$ classes than the pigs being fed near the ad lib. level (HFL). On average the $\mathrm{CH}_{4}$ excretion was $23 \%$ lower than that on HFL. A Student's $t$ test on individual differences between HFL and LFL (paired $t$ test) showed a mean difference of 0.8 litres $\mathrm{CH}_{4} / \mathrm{d}$, being highly significant $(P<0.001)$. However, in relation to the intake of dry matter (DM) the LFL group showed the greatest $\mathrm{CH}_{4}$ excretion with a mean value of 3.1 (SE 0.21 ) litres $/ \mathrm{kg} \mathrm{DM} \mathrm{v.} 2.5$ (SE 0.14) litres $/ \mathrm{kg} \mathrm{DM}$ for the HFL group, the difference being significant $(P<0 \cdot 05)$.

The $\mathrm{CH}_{4}$ excretion in Expt $\mathrm{B}$ increased linearly to about $70 \mathrm{~kg} \mathrm{LW}$ when a plateau was reached for both diets, being about 12 litres/d for pigs fed on the -oil diet and about 10 litres/d for pigs fed on the +oil diet. On average the inclusion of oil reduced $\mathrm{CH}_{4}$ excretion by $26 \%$ during the growth period. One-way ANOVA on the differences between groups fed on the +oil and -oil diets in eight periods showed a mean difference of 1.9 litres $\mathrm{CH}_{4} / \mathrm{d}$, being highly significant $(P<0.001)$. In relation to intake of DM the mean $\mathrm{CH}_{4}$ excretion in periods 4-8 was $5 \cdot 2$ (SE 0.14) and $4 \cdot 3$ (SE $0 \cdot 15)$ litres $/ \mathrm{kg}$ DM for the - oil and + oil diets respectively, the difference being highly significant $(P<0.001)$.

The $\mathrm{CH}_{4}$ excretion on a DM basis was greater for the pigs receiving the semi-purified diet (Expt B) than for the pigs fed on the commercial diet (Expt A), and all differences between Expts $\mathrm{A}$ and $\mathrm{B}$ were highly significant $(P<0.001)$.

\section{DISCUSSION}

Carbohydrate fermentation in the rumen yields volatile fatty acids, $\mathrm{CO}_{2}$ and $\mathrm{H}_{2}$ and most of the $\mathrm{H}_{2}$ is used in the reduction of $\mathrm{CO}_{2}$ to $\mathrm{CH}_{4}$ (Hungate, 1968). In the hind-gut of pigs the proportions of individual volatile fatty acids were found to be similar to those in the rumen (Kidder \& Manners, 1978), and it is generally accepted that qualitatively the 
Table 3 . Expt A. Daily methane excretion in growing pigs fed on commercial mixtures at high (HFL) or low (LFL) feed levels*

(Mean values with their standard errors)

\begin{tabular}{|c|c|c|c|c|c|c|c|c|c|c|c|c|}
\hline \multirow{3}{*}{$\begin{array}{c}\text { Weight } \\
\text { range } \\
(\mathrm{kg})\end{array}$} & \multirow{2}{*}{\multicolumn{2}{|c|}{$\begin{array}{l}\text { No. of } \\
\text { measure- } \\
\text { ments }\end{array}$}} & \multicolumn{4}{|c|}{ Live wt (kg) } & \multirow{2}{*}{\multicolumn{2}{|c|}{$\begin{array}{l}\text { Dry matter } \\
\text { intake }(\mathrm{g})\end{array}$}} & \multicolumn{4}{|c|}{$\mathrm{CH}_{4}$ excretion (litres) } \\
\hline & & & \multicolumn{2}{|c|}{ HFL } & \multicolumn{2}{|c|}{ LFL } & & & \multicolumn{2}{|c|}{ HFL } & \multicolumn{2}{|c|}{ LFL } \\
\hline & HFL & LFL & Mean & SEM & Mean & SEM & HFL & LFL & Mean & SEM & Mean & SEM \\
\hline $20-25$ & 20 & 20 & $23 \cdot 1$ & 0.39 & $22 \cdot 2$ & 0.65 & 750 & 518 & 1.66 & 0.24 & $1 \cdot 33$ & 0.24 \\
\hline $25-35$ & 16 & 16 & $31 \cdot 5$ & 0.75 & $30 \cdot 4$ & $1 \cdot 12$ & 1115 & 759 & $2 \cdot 42$ & $0 \cdot 18$ & $2 \cdot 16$ & 0.28 \\
\hline $50-60$ & 8 & 8 & $57 \cdot 2$ & $1 \cdot 26$ & $54 \cdot 9$ & 1.81 & 1785 & 1071 & $4 \cdot 11$ & 0.46 & $3 \cdot 18$ & 0.54 \\
\hline $65-75$ & 4 & 4 & $70 \cdot 8$ & $3 \cdot 57$ & $69 \cdot 5$ & $2 \cdot 47$ & 2052 & 1339 & $5 \cdot 80$ & 1.46 & 3.47 & $1 \cdot 15$ \\
\hline $90-100$ & 8 & 8 & $95 \cdot 8$ & 1.59 & $93 \cdot 2$ & $2 \cdot 40$ & 2677 & 1339 & $7 \cdot 69$ & 0.86 & $5 \cdot 23$ & $0 \cdot 40$ \\
\hline $105-120$ & 7 & 7 & 110.9 & $2 \cdot 15$ & $109 \cdot 6$ & $2 \cdot 50$ & 2677 & 1785 & $8 \cdot 50$ & 0.95 & $7 \cdot 78$ & 0.68 \\
\hline
\end{tabular}

* For details of diets and levels of feeding, see p. 356 and Table 1.

Students $t$ test on sixty-three individual differences between HFL and LFL (paired $t$ test) showed a mean difference of 0.8 litres $/ \mathrm{d}$ with a $t$ value of $3.59(P<0.001)$.

Table 4. Expt B. Daily methane excretion in growing pigs fed on semi-purified diets without ( - oil) or with (+oil) addition of soya-bean oil

(Mean values with their standard errors)

\begin{tabular}{|c|c|c|c|c|c|c|c|c|c|c|c|}
\hline \multirow{3}{*}{$\begin{array}{c}\text { Balance } \\
\text { period } \\
\text { no. }\end{array}$} & \multirow{2}{*}{\multicolumn{2}{|c|}{$\begin{array}{c}\text { No. of } \\
\text { measure- } \\
\text { ments }\end{array}$}} & \multicolumn{4}{|c|}{ Live wt $(\mathrm{kg})$} & \multirow{3}{*}{$\begin{array}{c}\begin{array}{c}\text { Dry matter } \\
\text { intake }(\mathrm{g})\end{array} \\
\begin{array}{c}\text { Both } \\
\text { groups }\end{array}\end{array}$} & \multicolumn{4}{|c|}{$\mathrm{CH}_{4}$ excretion (litres) } \\
\hline & & & \multicolumn{2}{|c|}{ - oil } & \multicolumn{2}{|c|}{ +oil } & & \multicolumn{2}{|c|}{ - oil } & \multicolumn{2}{|c|}{ +oil } \\
\hline & - oil & +oil & Mean & SEM & Mean & SEM & & Mean & SEM & Mean & SEM \\
\hline 1 & 4 & 4 & 28.0 & 0.41 & $29 \cdot 1$ & 0.30 & 987 & 1.88 & $0 \cdot 36$ & $1 \cdot 13$ & $0 \cdot 38$ \\
\hline 2 & 4 & 4 & $37 \cdot 3$ & 0.76 & 39.6 & 0.23 & 1257 & 3.76 & 0.40 & 2.66 & 0.95 \\
\hline 3 & 4 & 4 & $47 \cdot 6$ & 0.78 & $51 \cdot 9$ & 0.15 & 1526 & 6.48 & 0.74 & 3.78 & $1 \cdot 32$ \\
\hline 4 & 4 & 3 & 57.4 & 0.71 & $64 \cdot 5$ & 0.29 & 1795 & $9 \cdot 12$ & 0.07 & $6 \cdot 49$ & 0.49 \\
\hline 5 & 4 & 3 & 68.9 & 1.09 & $77 \cdot 0$ & 0.70 & 2038 & $10 \cdot 70$ & 0.61 & $9 \cdot 31$ & 0.98 \\
\hline 6 & 4 & 3 & $81 \cdot 1$ & 1.07 & $89 \cdot 7$ & 1.87 & 2304 & $12 \cdot 19$ & 1.06 & 9.99 & 0.49 \\
\hline 7 & 4 & 3 & $91 \cdot 2$ & 0.92 & $101 \cdot 7$ & 1.77 & 2482 & 11.86 & 0.56 & 10.08 & 0.64 \\
\hline 8 & 4 & 3 & 107.0 & 0.36 & $115 \cdot 0$ & $1 \cdot 34$ & 2127 & $12 \cdot 23$ & 0.66 & 9.66 & 0.31 \\
\hline
\end{tabular}

* For details of diets and levels of feeding, see p. 356 and Table 1.

One-way ANOVA on the differences between groups on - oil or + oil in eight periods showed a mean difference of 1.9 litres/d with an $F$ value of $7.18(P<0.001)$.

fermentative processes are the same as in the rumen. Both $\mathrm{CH}_{4}$ and $\mathrm{H}_{2}$ are expired in the pig, but breath $\mathrm{CH}_{4}$ concentrations are about ten times greater than breath $\mathrm{H}_{2}$ concentrations (Fleming \& Wasilewski, 1984) indicating that $\mathrm{H}_{2}$ is being used in the formation of $\mathrm{CH}_{4}$. In the present study all pigs ( $n$ 36) excreted $\mathrm{CH}_{4}$, but twelve pigs excreted very small amounts of $\mathrm{CH}_{4}$ in the lower weight classes. From 20 to $25 \mathrm{~kg} \mathrm{LW}$ the mean excretion was about 1 litre $\mathrm{CH}_{4} / \mathrm{d}$, increasing to about 12 litres $/ \mathrm{d}$ at $80-115 \mathrm{~kg} \mathrm{LW}$. These amounts of $\mathrm{CH}_{4}$ represented a daily energy loss of $40-480 \mathrm{~kJ}$, which corresponds to no more than $1.2 \%$ of daily GE intake. Under the dietary conditions used here it seems that this energy loss is not an important consideration for feed evaluation. Individual variations in $\mathrm{CH}_{4}$ excretion as expressed by the $\mathrm{CV}$ were considerable, ranging from 2 to $70 \%$. Considerable variation 
in gas production was also noted in the response of humans to an individual diet (Marthinsen \& Fleming, 1982).

The results (Table 3) from pigs fed on a commercial diet (Expt A) showed that the daily $\mathrm{CH}_{4}$ excretion increased linearly with increasing $\mathrm{LW}$. The highest values were measured on HFL (near ad lib. intake), probably because a greater amount of undigested material reached the hind-gut. As the increase in $\mathrm{CH}_{4}$ excretion was linear both on HFL and LFL, the microbes apparently were able to ferment the probably greater amounts of undigested material being transported to the hind-gut of animals fed on HFL. The results (Table 4) from pigs receiving the semi-purified diet (Expt B) showed that on this diet there was an upper limit in the capacity of the actual microbial population to ferment the material, as the $\mathrm{CH}_{4}$ excretion remained constant above an intake of $2100 \mathrm{~g} \mathrm{DM}$ daily.

On a DM basis $\mathrm{CH}_{4}$ excretion in Expt A was 3.1 and 2.5 litres $/ \mathrm{kg} \mathrm{DM}$ on LFL and HFL respectively, which may be due to differences in transit times through the gastrointestinal tract. The $\mathrm{CH}_{4}$ excretion in Expt B for periods $4-8$ was $5 \cdot 2$ and $4 \cdot 3$ litres $/ \mathrm{kg} \mathrm{DM}$ on -oil and + oil diets respectively which, compared with the results from pigs on a commercial diet (Expt A), indicate that apparently more of the carbohydrates from cassava meal and maize starch escaped enzymic degradation and absorption in the small intestine, leaving more material for fermentation in the hind-gut. The transit time may also be greater for this feed.

The results from Expt $\mathrm{B}$ showed that addition of $90 \mathrm{~g}$ soya-bean oil $/ \mathrm{kg}$ diet ( + oil) reduced $\mathrm{CH}_{4}$ excretion by an average of $26 \%$ during the growth period compared with the oil-free diet. The depressive effect of relatively large amounts of unsaturated fat or fatty acids on microbial activity and hence on $\mathrm{CH}_{4}$ excretion is well known in ruminants (Czerkawski et al. 1966; Rohr \& Okubo, 1968; Czerkawski, 1976). Full-fat soya-bean meal produced less flatus than defatted soya-bean meal in humans (Steggarda et al. 1966). The inclusion of $350 \mathrm{~g}$ beef fat or safflower oil $/ \mathrm{kg}$ in a basal, purified, low-fat diet significantly reduced the number of caecal bacteria and decreased most of the microbial enzyme activities in the caecum of rats (Mallett et al. 1983). Thus, there seem to be similarities in the depression of fat on microbial fermentation and hence on flatus production in ruminants, rats, humans and pigs.

The pig has been of interest as a model to study flatulent factors in humans as it is similar to man in its nutritional gastrointestinal physiology (Pond \& Houpt, 1978). In humans intestinal fermentation always yields $\mathrm{H}_{2}$, but apparently $\mathrm{CH}_{4}$ is not a universal component. The proportion of healthy adults excreting $\mathrm{CH}_{4}$ in the breath varied from 22 to $70 \%$ (Calloway \& Murphy, 1968; Bond et al. 1971; Pitt et al. 1980).

Cancer of the colon (Haines et al. 1977; Piqué et al. 1984) and abdominal arterial disease (McKay et al. 1983) have been reported to be associated with a high incidence of $\mathrm{CH}_{4}$ excretion. In man, the biochemical pathway of $\mathrm{CH}_{4}$ production seems to be different from that in the rumen, as it is not entirely dependent on the concentration of $\mathrm{H}_{2}$ (Calloway, 1966; McKay et al. 1981). Human breath contains twice as much $\mathrm{H}_{2}$ as pig breath, and only about one-twentieth of pig breath $\mathrm{CH}_{4}$ concentrations (on quite different diets), but changes due to dietary manipulations seemed to be qualitatively similar (Fleming \& Wasilewski, 1984). In human breath, $\mathrm{H}_{2}$ concentrations did not provide an adequate predictor of flatus gas excretion, but breath and flatus $\mathrm{CH}_{4}$ excretions were highly correlated (Marthinsen \& Fleming, 1982). Lewitt (1985) concluded that the only feasible method to reduce flatus production at the present time appears to be the use of a diet that reduces the quantity of carbohydrate reaching the colon, namely a lactose-free, low-wheat diet. The present findings and those of others suggest that a daily intake of a polyunsaturated oil might also be helpful in reducing the amount of intestinal gas. 


\section{REFERENCES}

Bond, J. H., Engel, R. R. \& Lewitt, M. D. (1971). Journal of Experimental Medicine 133, 572-588.

Breirem, K. (1935). National Institute of Animal Science Report no. 162, 0-269. Copenhagen: Landhusholdningsselskabets Forlag.

Brouwer, E. (1965). In Proceedings of the 3rd Symposium on Energy Metabolism. European Association of Animal Production Publication no. 11, pp. 441-443. London: Academic Press.

Calloway, D. H. (1966). Gastroenterology 51, 383-389.

Calloway, D. H. \& Murphy, E. L. (1968). Annual of the New York Academy of Sciences 150, 82-95.

Christensen, K. (1985). National Institute of Animal Science Report no. 577, 0-158. Copenhagen: Landhusholdningsselskabets Forlag.

Czerkawski, J. W. (1976). In Proceedings of the 7th Symposium on Energy Metabolism. European Association of Animal Production Publication no. 19, pp. 69-72. Clermont-Ferrand, France: G. de Bussac.

Czerkawski, J. W., Blaxter, K. L. \& Wainmann, F. W. (1966). British Journal of Nutrition 20, 485-494.

Fleming, S. E. \& Wasilewski, M. M. (1984). Nutrition Reports International 30, 825-834.

Haines, A., Metz, G., Dilawari, J., Blendis, L. \& Wiggins, M. (1977). Lancet ii, 481-483.

Hoffmann, L., Jentsch, W., Klein, M. \& Schiemann, R. (1977). Archiv für Tierernährung 27, 421-438.

Hungate, R. E. (1968). In Handbook of Physiology, vol. 5, pp. 2725-2745 [C. F. Code, editor]. Washington, DC: American Physiological Society.

Jentsch, W. \& Hoffmann, L. (1977). Archiv für Tierernährung 27, 491-507.

Kidder, D. E. \& Manners, M. J. (1978). Digestion in the Pig. Bristol: Scientechnica.

Lewitt, M. D. (1985). Proceedings of the Nutrition Society 44, 145-146.

McKay, L. F., Brydon, W. G., Eastwood, M. A. \& Housley, E. (1983). Atherosclerosis 47, 77-81.

McKay, L. F., Brydon, W. G., Eastwood, M. A. \& Smith, J. H. (1981). American Journal of Clinical Nutrition 34, 2728-2733.

Mallett, A. K., Rowland, I. R. \& Wise, A. (1983). Proceedings of the Nutrition Society 43, 7A.

Marthinsen, D. \& Fleming, S. E. (1982). Journal of Nutrition 112, 1133-1143.

Piqué, J. M., Pallarés, M., Cosó, E., Vilar-Bonet, J. \& Gassull, M. A. (1984). Gastroenterology 87, $601-605$.

Pitt, P., DeBruijn, K. M., Beeching, M. F. \& Goldberg, E. (1980). Gut 21, 951-959.

Pond, W. G. \& Houpt, K. A. (1978). Biology of the Pig. New York: Comstock Publisher Association.

Rohr, K. \& Okubo, M. (1968). Milchwissenschaft 23, 608-614.

Snedecor, G. W. (1956). Statistical Methods Applied to Experiments in Agriculture and Biology. Iowa: The Iowa State College Press.

Steggarda, F. R., Richards, E. A. \& Rackis, J. F. (1966). Proceedings of the Society of Experimental Biology and Medicine 121, 1235-1239.

Thorbek, G. (1969). National Institute of Animal Science Report no. 373, pp. 0-46. Copenhagen: Landhusholdningsselskabets Forlag.

Thorbek, G. (1980). National Institute of Animal Science Report no. 498, pp. 0-95. Copenhagen: Landhusholdningsselskabets Forlag.

Thorbek, G., Chwalibog, A. \& Henckel, S. (1984). National Institute of Animal Science Report no. 563, pp. 0-114. Copenhagen: Landhusholdningsselskabets Forlag.

Van der Honing, Y., Jongbloed, A. W., Smits, B. \& Wieman, B. J. (1982). In Proceedings of the 9th Symposium on Energy Metabolism. European Association of Animal Production Publication no. 29, pp. 202-205. Ski, Norway: Informasjonsteknikk $\mathbf{A} / \mathrm{S}$.

Verstegen, M. V. A. (1971). Mededelingen van de Landbouwhoegeschool te Wageningen 71-2, 0-115. 